\title{
International Hotel Strategy and Institutional Distance: A Conceptual Framework
}

\author{
Sven Dahms ${ }^{1}$ \\ ${ }^{1}$ Department of International Business Administration, I-Shou University, Kaohsiung, Taiwan \\ Correspondence: Sven Dahms, Department of International Business Administration, I-Shou University, \\ Kaohsiung, Taiwan. E-mail: svendahms@hotmail.com
}

Received: March 9, 2015

Accepted: April 14, 2015

Online Published: May 22, 2015

doi:10.5539/ijbm.v10n6p90

URL: http://dx.doi.org/10.5539/ijbm.v10n6p90

\begin{abstract}
In recent international hotel strategy literature, institutional differences between home and host country have been mostly neglected. Although concepts such as institutional distance have become more prevalent as analytical tools in the mainstream international business literature, not much of it has so far been adopted in the wider field of international hospitality management. The objective of this article is to propose a conceptual framework that is based on insights from new institutional economics in order to further our understanding of international strategies for hotels. It introduces the concept of institutional distance as a supplement to Yip's popular global strategy framework. This article aims at providing a template for active researchers in the field to embed their empirical contributions within the wider international business literature.
\end{abstract}

Keywords: international hotels, institutional distance, new institutional economics, international strategic management

\section{Introduction}

The fact that most multinational enterprises in this world are not 'global' but rather regional in nature has long been established in the mainstream international business literature (Rugman, 2005). Lately this argument also found its way into the travel and tourism (Aramberri, 2009), as well as hospitality management literature (Whitla et al., 2007; Littlejohn et al., 2007).

Factors that seem to manifest this lack of globalisation in the hospitality industry are manifold such as regulations, most markedly visa restrictions for travellers, labour legislation, local competition intensity, high human asset specificity, cultural distance, or legal enforcement (Ayoun \& Moreo, 2008; Rugman \& Verbeke, 2008; Aramberri, 2009; Martorell et al., 2013). All those factors are institutional in nature. The need to acknowledge institutional differences between countries has been emphasised for example by Aramberri (2009) and Littlejohn et al. (2007). The authors also point to the importance of the local markets for international hotels, in particular local guests, which make the major share across destinations for sites in varying host locations (ibid.). For the international hotel industry, that implies that there has to be the right mix to be found between internal and external factors that influence strategic decisions (Zhao \& Olsen, 1997; Olsen et al., 2008).

Although various attempts have been made to explain the phenomenon of international hotels expansion and engagement in host countries, most studies seem to lack a coherent theoretical framework to categorise and explain their findings (Harrington \& Ottenbacher, 2011). For example, in a recent comprehensive study by Gannon et al. (2010), the authors point towards various human resources related difficulties that international hotels face when focussing on contracting rather than owning the property in the host country. Although aspects of cultural distance and agency theory are discussed, the key enabling or frictional characteristics of institutions have not been integrated in their framework. Zhang et al. (2012) investigate the investment choice of multinational hotel groups in China. Although institutional factors have been considered in both articles, no theoretical framework has been provided.

This relates to the more common issue in hospitality management research in which studies present their findings in a rather descriptive way, without pointing out the valuable theoretical contributions their findings imply (Okumus, 2002). Even in popular streams of the hospitality management literature such as entry modes (Contractor \& Kundu, 1998; Leon-Darder et al., 2011; Villar et al., 2012) or knowledge flow studies (Martorell 
et al., 2013), an institutional discussion is missing and articles overly rely on a simplistic frictional perspective on institutions. Much less is being said about the strategic development of international hotels sites in institutional distant locations. Furthermore, formal institutions are predominantly viewed as frictional, but rarely as enablers for strategic decisions (Dahms, 2014; Martin, 2014).The reasons for that could be twofold. The first point concerns the theoretical development of the field. Entry-mode studies and the concept of cultural distance in particular played a predominant role over the last decades in the mainstream international business literature (Rugman et al., 2011; Zaheer et al., 2012), which also might have had an effect on related fields such as hospitality management. Second, international hotel strategy has so far been mostly seen as streaming from developed to developing countries. Hence, the view that institutions are more frictional (e.g. corruption, political risk, etc.) than enabling (competition, networks, human capital, etc.) in nature comes less of a surprise. Research on international hotel strategy in the other direction is still in its infancy (Johnson \& Vanetti, 2005; Gammeltoft, 2008; Peng et al., 2008).

The objective of this article is to propose a coherent framework for the analysis of international hotels concerning their strategy patterns in relation to institutional differences between home and host country. This is also in line with Littlejohn's et al. (2007) call to integrate cultural diversity, as well as policy dimensions in hospitality management research. Following Lovelock and Yip (1996), international hotels are defined as entities that provide people-processing services in at least one other country than their home country. The present article builds on existing research in the fields of new institutional economics (e.g. North, 1990; Williamson, 2000), international business (e.g. Rugman et al., 2011) and hospitality management (e.g. Whitla et al., 2007). It aims to allow researchers to include a coherent theoretical perspective while investigating international hotel strategy and to develop robust conclusions which can contribute to theory and practise. In particular, it proposes a framework based on reasoning embedded in new institutional economics literature (North, 1990; Williamson, 2000). This study therefore argues that formal and informal institutional differences between home and host country play a decisive role for international strategies of hotels. This framework is further expanded into the application of institutional distance, which provides a theoretical consistent and empirically well-established lens in international business literature to investigate empirically the proposed effects (c.f. Zaheer et al., 2012). It is thereby connected with the 'global levers' typology, used extensively in the hospitality management literature (e.g. Whitla et al., 2005, Whitla et al., 2007) as developed by Yip (1992). This allows to narrow gaps in the broader international hotel literature, but also aims to provide guidance to overcome some of the shortcomings identified in the strategy literature concerning Yip's framework (Whitla et al., 2005) and strategic hospitality management literature (Harrington \& Ottenbacher, 2011). This paper proceeds in a brief discussion on the relevance of Yips framework for the international hotel industry, before discussing the concepts of formal and informal institutions and institutional distance. The fourth part develops propositions based on a modification of Yip's strategy framework on the effects of institutional distance on strategic decisions in the international hotel industry. The article concludes by pointing out the contribution of the proposed framework and avenues for further research, as well as its limitations.

\section{Yip's Framework of Global Strategy in International Hospitality Management Literature}

This section discusses the work of Yip on global strategic management and its application in hospitality management research. The purpose is thereby to lead up towards a discussion of the arrows rather than the boxes, as demanded in international business research by Thomas et al. (2011).

Whitla et al. (2005) stated that Yip's framework of global strategy has been rather underutilised in the broader strategy literature. The authors point towards four main potential shortcomings of Yip's framework, which might have contributed to this development. Those are its focus on the industrial organisation perspective, the theoretical underpinnings, incomplete specification of the framework, and potential omissions. While not all of the criticism can be discussed here, this paper attempts to overcome some of those, especially related to the theoretical underpinnings while using NIE to enrich Yip's framework.

This article proposes relationships between the concept of institutional distance and global levers. It is thereby argued that institutional distance can provide an additional lens through which the globalisation drivers (i.e. market, costs, government, and competition) can be viewed. Institutional distance is thereby seen as an envelope that captures those industry globalisation drivers in a synergetic way. In other words, instead of using the term 'global drivers', recent evidence indicates that differences between home and host country might be more suitable to explain international strategic decisions in the international hotel and other industries (Rugman \& Verbeke, 2008; Beugelsdijk \& Mudambi, 2013).

Therefore, this paper is following the line of arguments brought forward by Whitla et al. (2005), stating that a 
more narrow focus, and the explicity of additional theoretical concepts can help improve Yips framework. Yips framework is seen as particularly relevant for the international hotel industry, given its wide popularity in the hospitality management literature. The next section outlines the particular understanding of institutions for this article, before it is introduced as a supplement to Yips framework.

\section{Formal and Informal Institutions}

The institutional perspective plays an increasingly important role in the wider international business literature (Peng et al., 2008; Martin, 2014; Dahms, 2014). Three main institutional perspectives can therein be identified. Firstly, the organisational theory based approaches that aim to explain intra-organisational behaviour of individuals as well as the concept of legitimacy of multinationals in host countries (DiMaggio \& Powell, 1983; Westney, 2005). Secondly, the so called 'thick' institutional approach, which combines insights from political science, sociology and economics, in order to describe patters related to differing institutional settings between countries, hence it is descriptive and comparative in nature (Redding, 2005). The third perspective is referred to as new institutional economics (NIE), which is largely based on the work of North (1990) and Williamson (2000).

In NIE, institutions are seen as 'the rules of the game' and hence determine the costs of transacting between economic actors reaching from governments to markets (North, 1990). Those transaction costs in turn affect the way institutions develop in countries, which is referred to as institutional path dependency. Institutions follow different development paths in different countries and hence create different institutional settings in each country. Those varying settings lead to inter-country differences in terms of technological development, entrepreneurial activity, trust, educational system, or efficiency of courts for example. In other words, the institutional setting in which a company operates determines the set of opportunities and transactions, which are both influenced by formal and informal institutional differences.NIE is a comparative perspective on the economic organisation of firms along the planes of transaction costs and governance (Henisz \& Williamson, 1999). This makes this perspective in particular relevant to the international business context in which transactions and company structure are embedded in numerous institutional contexts. NIE bridges therefore the levels of institutions and firms (Martin, 2014; Dahms, 2014). It allows a predictive; economics based perspective on institutions that is in line with broader international business strategy frameworks due to similar underlying and transparent assumptions such as bounded reliability, non-zero contracting costs, and asymmetric information, which are prevalent in internalisation theory (Henisz \& Williamson, 1999; Verbeke \& Greidanus, 2009). This particular view on institutions makes it possible to understand institutional differences and their potential advantages, such as location-specific advantages in form of abundant inter-firm networks or human capital (Dahms, 2014). In the same time, it leaves enough room to argue for the potential of firm-specific advantage creation and transfers by firms and their subsidiaries through an advanced intra-firm network for instance (Rugman \& Verbeke, 2001).

Although NIE has been used in the international hotel literature, especially concerning entry modes (e.g. León-Darder et al., 2011, Villar et al., 2012; Martorell et al., 2013) its application is often lacking in depth concerns for theoretical consistency, and might not have been used to its full potential. However, this is not unique to the international hotel literature. Peng et al. (2008) point out that the broader international business literature has treated institutions so far mostly as a control variable. This might have led to an underestimation of the behaviour shaping influence institutions can have on economic actors. That resulted in a continued focus on industrial organisation economics frameworks to explain the majority of empirical findings in international hotel strategy papers such as in Pine and Qi (2004), Whitla et al. (2007) or Gannon et al. (2012).

Formal institutions are defined in this paper, following North (1990) and Henisz and Williamson (1999), as consisting of political rules, legal rules and contracts, and economic rules, which create institutional differences between countries. Economic institutions refer therein mainly to issues surrounding the efficiency of property rights protection as well as market transparency and market efficiency. Political rules consist of political decision-making processes and transparency, as well as bureaucratic hurdles. Legal rules refer to the efficiency of the judicial system and the legal system prevalent in a country (ibid.).

Informal institutions consist of customs, language, beliefs, and habits. These have been described by North (1990) and Williamson (2000) as the foundation of formal institutions. However, in defining informal institutions from a norms and values perspective, the definition used in the current study distinguished itself from the non-rational factor definition, often labelled as 'culture' (De Jong, 2009; Leung et al., 2011). Within this approach, culture is seen "as a rest factor explaining the difference between a theory's prediction and the facts" (De Jong, 2009, p. 32). For this study, informal institutions are seen as a main explanatory variable that shapes the actions of human actors (North, 1990; Langlois, 2006). Informal institutions are fundamental in the understanding of international 
hotel engagement in host countries, especially given the dominance of local rather than global expectations on hospitality (Brotherton, 1999). The next section discusses the application of NIE in the concept of institutional distance.

\subsection{Institutional Distance}

Institutional distance is, in line with relevant literature, defined as an approximation of the extent to which countries differ in their institutional settings (Xu \& Shenkar, 2002; Rugman et al., 2011).Institutional distance is a concept that allows researchers to quantitatively investigate the institutional differences between home and host country based on various secondary data sources. Although the concept is not without its shortcomings (c.f. Shenkar, 2001; Zaheer et al., 2012; Dahms, 2014), it has various advantages, which appear at the current stages of research, outweigh its disadvantages. Firstly, it is a concept that has emerged from the early entry mode studies related to transaction cost economics that provides a theoretical coherence with prevailing organisational economics theories in international business frameworks (Kogut \& Singh, 1988). Transaction cost economics forms a large part of the NIE literature and is seen hence as compatible with its underlying assumptions such as asymmetric information, adverse selection and bounded reliability (Verbeke \& Greidanus, 2009). Secondly, it is a concept that has been widely accepted as a tool to quantify institutional differences in the more recent empirical literature (c.f. Zaheer et al., 2012). This allows testing and comparing the theoretical implications with previous empirical and conceptual research and hence facilitates a stepwise knowledge building process in the field (ibid.). Thirdly, it allows researchers to be more aware of the boundaries of their research and being widely seen as less descriptive than the macro-institutionalist approach (Knutsen, 2004). This makes the concept of institutional distance suitable to systematically investigate the effects of differing transactional costs between home and host country, in particular strategy implications for international hotels.

The following section describes how the concept of institutional distance can be used to investigate strategic decisions in international hotel chains while proposing a modification to Yips framework of global levers.

\section{The Proposed Framework Linking Institutional Distance and Yip's Global Levers}

This section aims to refine and to extend Yip's (1992) framework on global strategies. Yip set out with the argument that industry specific global drivers determine the globalisation strategy of multinationals. The author further stated that those global drivers affect global strategy levers, which narrow the strategic choices for a company. It has been also implicated that company specific resources play a role therein as well. Those resources, often labelled as firms specific advantages, have been discussed widely in the international business literature and shall not be the focus of this article (e.g. Buckley \& Casson, 1976; Rugman \& Verbeke, 2008). This article, however, proposes that instead of attempting to capture global drivers for an industry, it might be more helpful to look at international hotel strategy from a country to country basis in order to understand the strategy levers for an international hotel. This proposed shift away from a 'global' view is based on two arguments in the current literature. First, the increasing importance of local markets i.e. local guests for international hotels as emphasised in hospitality management literature (e.g. Littlejohn et al., 2007; Aramberri, 2009). Second, the move in the broader international business literature away from 'global' perspectives, towards inter-country or intra-regional strategies (Rugman, 2005; Rugman et al., 2011).

Accordingly, the proposed country to country emphasis is achieved in the current paper by systematically comparing the institutional distance between home and host country and hence derive at more carefully crafted conclusions and recommendations for the phenomena of international hotel strategic engagement in a particular host country. Following a recent, and maybe more down to earth perspective on international business activities (Rugman, 2005), the current study is refining some terminology of Yip's original framework. For example, industry globalisation drivers are embedded in the concept of institutional distance. Market, cost, government, and competition, as discussed by Yip (1992) are fundamental pillars of the institutional setting in each country (North, 1990; Williamson, 2000). Those institutions create transaction cost differentials for any company conducting business between any two or more given countries. Those differing costs of transaction are represented here by the concept of institutional distance. Additionally, strategic levers will appear without the term 'global'. This is because, with a few exceptions, the majority of international hotels rarely operate globally, but are more concerned with international operations within their home regions, or outside of their home base merely entertain few flagship sites in order to cater to international business travellers (Whitla et al., 2007; Rugman \& Verbeke, 2008). Strategy levers are: market participation, standardisation of services, location of activities, marketing and strategy. The terms are defined in table 1. 
Table 1. Definitions of strategy levers

\begin{tabular}{|c|c|c|}
\hline Strategy levers & Definition & Examples of relevant hospitality management studies \\
\hline $\begin{array}{l}\text { Market } \\
\text { participation }\end{array}$ & $\begin{array}{l}\text { The selection of countries for market entry including } \\
\text { the depth of engagement (e.g. number of sites, } \\
\text { contracts, franchise, etc.) in the host country }\end{array}$ & $\begin{array}{l}\text { Contractor and Kundu, 1998; Contractor et al., 2003; Yang } \\
\text { and Wang, 2004; Hallin and Marnburg, 2008; Zhang et al. } \\
2012\end{array}$ \\
\hline $\begin{array}{l}\text { Standardisation of } \\
\text { services }\end{array}$ & $\begin{array}{l}\text { The decision to standardise services to varying } \\
\text { degrees across the international operations }\end{array}$ & $\begin{array}{l}\text { Bouncken, 2002;Pine and Qi, 2004, Chen and Dimou, 2005, } \\
\text { Baum, 2006; Groschl and Doherty, 2006; Whitla et al. } \\
\text { 2007; Hsieh and Tsai, 2009; Gannon et al., 2012 }\end{array}$ \\
\hline $\begin{array}{l}\text { Location } \\
\text { activities }\end{array}$ & $\begin{array}{l}\text { The international location of activities across the } \\
\text { entire value chain }\end{array}$ & $\begin{array}{l}\text { Bouncken, 2002; Whitla et al., 2007; Gannon et al., 2012 } \\
\text { Brookes and Roper, } 2012\end{array}$ \\
\hline Marketing & $\begin{array}{l}\text { The extent to which marketing activities and } \\
\text { branding are standardised across international } \\
\text { operations }\end{array}$ & $\begin{array}{l}\text { Pine and Qi, 2004; Johnson and Vanetti, 2005; Whitla et al. } \\
2007\end{array}$ \\
\hline Strategy & $\begin{array}{l}\text { The extent to which competition influences strategic } \\
\text { decisions }\end{array}$ & $\begin{array}{l}\text { Davies, 1999; Pine and Qi, 2004; Espino-Rodríguez and } \\
\text { Padrón-Robaina, 2005; Whitla et al., } 2007\end{array}$ \\
\hline
\end{tabular}

Source: Adapted from Yip (1992).

The following figure represents the framework that will be discussed further below. In order to distinguish between each institutional pillar, formal and informal institutional distance and their effects on strategy levers will be discussed separately.

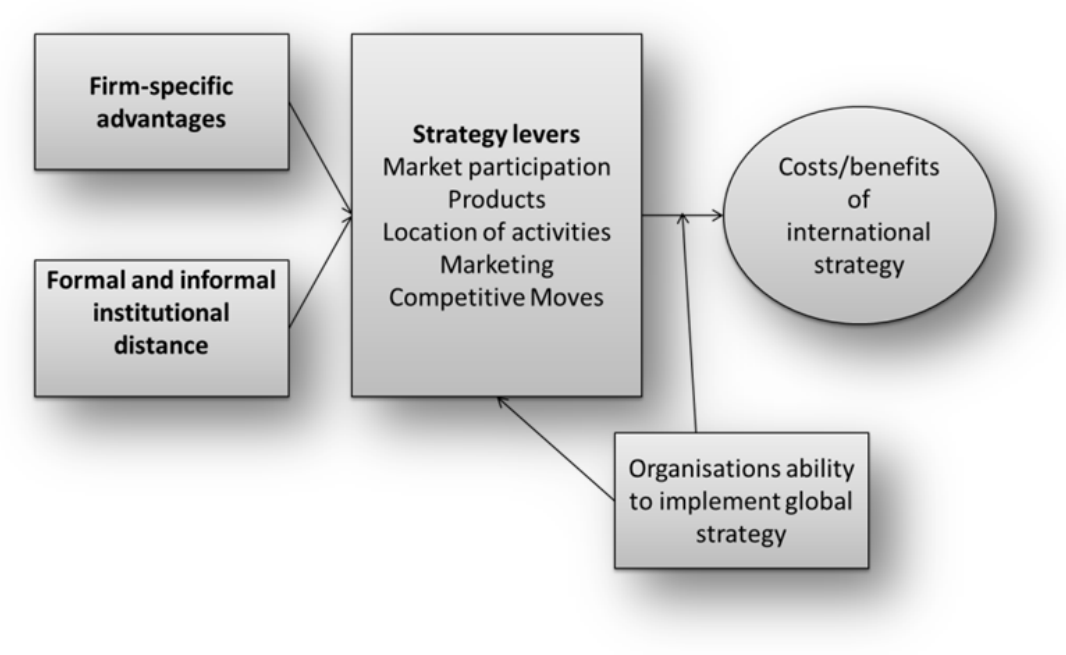

Figure 1. Revised framework

Adapted from Yip (1992).

\subsection{Formal Institutional Distance and Strategy Levers}

\subsubsection{Market participation}

Formal institutional transaction cost differentials between home and host country might play a decisive role in the willingness of a hotel to participate in distant host countries markets and hence contribute to the international spread of its business model. Countries located at a larger formal institutional distance might provide the hotel with institution (path-) dependent knowledge sources. Those can evolve around certain business processes, which might not be easily implemented or adapted while not being present in such a host location (Verbeke \& Campbell, 2001; Pine \& Qi, 2004). Even more so, the learning process might require local presence (Yang \& Wang, 2004). Knowledge that emerges from a particular institutional setting, for example, relevant qualifications 
of the local workforce, educational institutions, or local supplier networks, all this might require a hotel to be present and hence, increases the incentive to develop a significant establishment in the host country, driven by formal institutional distance. Empirical evidence for that has been limited mostly to a national level only, international hotel management research is still in its infancy (Yang \& Wang, 2004; Hallin \& Marnburg, 2008; Zhang et al., 2012).

\subsubsection{Standardisation of Services}

Services might be standardised initially in order to exploit economies of scale and scope (Rugman \& Verbeke, 2008). However, the learning process is expected to lead to a stepwise adoption of regional or local standards in order to back feed best practises to the rest of the multinational. That means, a standardisation of services in host countries at a greater formal institutional distance, might prevent the hotel chain from learning, in addition to repel potential local guests (Bouncken, 2002; Pine \& Qi, 2004; Hsieh \& Tsai, 2009). Furthermore, it might well be expected that host country rules and regulations play a significant role here. In particular, whereas it is commonly considered to be the case that in high risk countries, international hotels will rely on their standardised services (it is thereby often assumed no such standard exists), in a less risk focussed interpretation of formal institutional distance, quite the opposite might hold to be true. This has been indicated in few human resources focussed studies that showed how difficult it is to standardise services and training practises for international hotels (e.g. Gannon et al., 2010). Hence, host countries at a larger formal institutional distance, might provide the opportunity to access human capital and local supplier networks that, due to its institutional roots, provide new and potentially even higher standards due to levels of competition, education, and labour market factors, which differ from the ones prevalent in the home country.

\subsubsection{Location of Activities}

Larger transaction cost differentials caused by formal institutional distance could be expected to increase the likelihood to locate more value adding activities within the host country. The nature of activities in the hotel business has been largely seen as localised, due to the difficulties in separation between upstream and downstream operations. That is, activities such as housekeeping or laundry are more likely to be located in the host country by necessity (Lovelock \& Yip, 1996). However, back office tasks, such as reservation systems have been found to be centralised (Whitla et al., 2007). This practise of localisation and transfer of activities, however, could imply a significant loss in the profitability of transferred firm-specific advantages (FSA) into the host location. This, in turn, could be offset by a reverse flow of best practises that could be gained from an adaption of FSA's in the host locations (Bouncken, 2002; Brookes \& Roper, 2012). FSA are competences or capabilities the firm possesses which can be transferred across borders (Rugman et al., 2011). Furthermore, this reverse flow might be of particular relevance because differing formal institutional settings can provide the grounds for the exploitation of new economies of scale and scope. Formal institutional distance between home and host country might hence lead to varying levels of profitability of activities within the network of international hotels. Activities are expected to be located according to their lowest costs of transaction within the international hotel network (Johnson \& Vanetti, 2005). The perspective of formal institutional differences might help in explaining the location of activities beyond the non-separability theorem as criticised for hospitality management in general by Brotherton (1999).

\subsubsection{Marketing}

It is widely suggested that because of the intangible nature of service products, that a global brand image and the ultimately standardised marketing strategy bring advantages for internationalised hotels (Whitla et al., 2007). This, however, has not been confirmed across all locations (Johnson \& Vanetti, 2005). Larger formal institutional distance can, so it is argued here, decrease the impact of standardised marketing strategies. While it is accepted that international travellers might recognise familiar brands, in countries at a larger formal institutional distance, however, it might well be assumed that the successfulness of such standardised promotional activities is very limited. This could be caused by a more intense competition in the host country which makes it more difficult to start high impact campaigns, as well as rules and regulations that might require international hotels to alter their promotional activities (Whitla et al., 2007). Larger formal institutional distance might bring higher costs of transaction for the adaptation of standardised marketing campaigns that could outweigh the costs of more localised marketing campaigns. On the positive side, this also implies that in such constellations a certain reverse transfer of marketing practises might be possible. In other words, increasing marginal costs for the localisation of standardised marketing strategies might lead, not only to an reduction of standardised campaigns, but to the development of unique local or regional approach that might create new FSA's within the international hotel network. 


\subsubsection{Strategy}

Formal institutional transaction cost differentials between home and host country are also likely to have an impact on the strategic position the company seeks in the host country. The fragmented nature of competition of the hotel industry in many host countries (Davies, 1999; Whitla et al., 2007) means that a careful consideration of the costs of transaction is essential. Indeed, larger formal institutional distance is seen as leading to various different ways of how firms compete in markets. Although the fragmentation of competition has been pointed out, it is argued here that differing intensities of competition can lead to more valuable experiences concerning for example innovative pressures within the industry (Pine \& Qi, 2004). The level of competition might hence, lead to the development of FSA's that could be transferred to other units within the organisational network (Rugman \& Verbeke, 2008). Furthermore, looking at competition in a less threatening way, it might also provide new opportunities for collaboration on various levels of the hotel service value chain, such as F\&B franchising or room service outsourcing (Espino-Rodríguez \& Padrón-Robaina, 2005). Hence, larger formal institutional distance can have a facilitating effect on the engagement of the international hotel in the host country.

This section discussed the impact formal institutional distance can have on the use of strategy levers in international hotels. This leads to the first proposition of this article.

Proposition 1: All things being equal, larger formal institutional distance has a positive association with the engagement of international hotels in the host location.

\subsection{Informal Institutional Distance and Strategy Levers}

\subsubsection{Market Participation}

Larger informal institutional distance is expected to lead to a less pronounced desire by international hotels to participate in such markets. Additional costs caused by increasing asymmetric information, risk of bounded reliability or adverse selection (Rugman \& Verbeke, 2008) are thereby seen as creating an unfavourable setting for the hotel to participate in. In line with that argument, previous evidence suggests that broader geographic coverage is not necessarily increasing firms' performance (Contractor et al., 2003). A number of international hotel chains develop, what could be described as 'flagship sites' in such distant markets (Aramberri, 2009). The reasons for that, so it is argued in this paper, go back to the basics of internalisation theory. It is believed that in order to participate in informal institutional distant markets, the costs of transferring home country specific competitive advantages to the host country might come at prohibitive costs (Rugman et al., 2011). Firms, hence limit their participation in such markets not because of a lack of growth opportunities, but because of limited abilities to adapt home grown FSA's to host country demands based on informal institutional differences. This is especially sensitive in service industry based on the simultaneous consumption characteristic (Rugman \& Verbeke, 2008). Indeed, it is argued here that the attempt to amend home grown FSA's to local requirements in informal institutional distant countries might make the firm watering its competitive advantage, and hence leading to a loss of competitive cost advantages (e.g. based on standardised management processes) or brand advantages (e.g. business guests might be less comfortable with a perceived change of services, that is commonly associated with a particular brand). Transaction cost differentials caused by larger informal institutional distance might hence be prohibitively high for an international hotel to engage in a particular market.

\subsubsection{Standardisation of Services}

Informal institutional distance is also expected to have impeding effects on the possibility to standardise service processes. Differing habits, norms and values, require in customer contact intensive industries such as the hospitality industry, a dire recognition of local demands and therefore a tailoring of service processes to local demands (Pine \& Qi, 2004; Littlejohn et al., 2007). Hotels in informal institutional distant countries do not operate in a corporate vacuum as it could be found for example in manufacturing sector (Rugman \& Verbeke, 2008). Hence, a potential equilibrium between services expected by frequent business travellers and local customers will be more difficult to achieve for hotel sites located in informal institutional distant countries. Even well developed and centralised reservation systems might be underused if not adapted to local demands. Such adaptations can go beyond a translation of the reservation system homepage into a different language (Whitla et al., 2007).

Similarly, the learning process is expected to lead to a stepwise adoption of regional or local standards in order to reverse transfer best practises into the rest of the international hotel network. However, standardisation of such services might be hindered by higher human asset specificity in which such standardised services are embedded (Groschl \& Doherty, 2006). Indeed, as Baum (2006) states, varying degrees of social norms and habits make it 
much more difficult to implement service standards in countries that have a very different informal institutional setting. This relates back to the path dependency argument discussed above, which implies that differing norms and social background in countries have an effect on the expectations of staff and guests in the host location (Hsieh \& Tsai, 2009). These additional costs for the standardisation of services, caused by larger investments into human specific assets, are expected to lead to barriers in standardisation of services for hotel sites located in countries at a larger informal institutional distance. In a related discussion, Chen and Dimou (2005), showed that asymmetric information, caused by larger informal institutional distance, in international hotel groups can hinder the standardisation of services across the international hotel network.

\subsubsection{Location of Activities}

Similar to the arguments made above are by definition various activities location bound. This means that certain FSA's have to be modified in order to achieve an acceptable level of performance in the host location (Rugman $\&$ Verbeke, 2008). This in turn decreases the potential to reap economies of scale and scope and hence might reduce the likelihood of a strong presence of hotel sites located in countries that are at a larger informal institutional distance.

Informal institutional distance might also lead to prohibitively high internalisation costs concerning the location of activities. FSA's are commonly transferred to the host country by the multinational in order to internalise external market imperfections (Rugman \& Verbeke, 2008). However, given the difficulties hotels face in separating downstream and upstream activities, a centralised approach seems much harder to achieve than in the manufacturing sector (Contractor et al., 2003). In particular, even hotel wide staff development schemes and other HR related issues might have to be significantly adapted to local standards (Gannon et al., 2012) and hence might diminish FSA's transferred into countries at a larger informal institutional distance.

\subsubsection{Marketing}

The advantages of a 'global' marketing strategy have been well covered in previous international hotel strategy literature (e.g. Crawford-Welch, 1991; Whitla et al., 2007). Larger informal institutional distance, however, might offset some of those advantages. For example, sites located in such host countries might be under the umbrella of a largely centralised marketing department. This might be deemed as especially harmful in locations in which particular perceptions of hotels vary and hence, advertisement and promotions might lose its value (Pine \& Qi, 2004). This might even get to the point that marketing activities in the host location might be limited to locations in which frequent guests such as business/frequent travellers pass through such as busy airports or train stations. Its impact might be limited, however, given that local potential guests might not be able to comprehend certain messages in a way that was intended by the international hotel.

\subsubsection{Strategy}

Larger informal institutional distance might also offset certain strategic decisions. For example, a first mover advantage might not have the intended effect for the hotel. Indeed, late movers and local competitors might gain more from the presence of the hotel than the international hotel itself (Rugman \& Verbeke, 2008). Late movers learn from the mistakes made by the early entrant, and local hotels quickly adopt practises to a local host country standard and hence lure customers away (Pine \& Qi, 2004). This might be especially expected to be the case if one considers that customers in informal institutional distant countries might feel less loyal to a very different style of hotel than they do feel towards local chains or foreign competitors that adapted more quickly to local demands. Lack of global competitive strategies have also been identified in Whitla et al. (2007), however, the authors did not search for explanations beyond competitive pressures or, related to that, the fragmentation of markets in host locations. This leads to the second proposition of this article.

Proposition 2: All things being equal, larger informal institutional distance has an impeding effect on the engagement of international hotels in host location.

\section{Conclusion}

This article argued that international hotels need to take into consideration the factors of formal and informal institutional distance between the home and host country for their strategic decisions. It proposed a bird's eye view on strategy, based on new institutional economics, international business, and Yip's global strategy framework as its key building blocks.

The objective of this article was to provide international hotel strategy researchers with a thinking template in order to further develop their theoretical contributions to the field. It thereby followed calls made in the wider international business and international hotel strategy literature in presenting a framework that is empirically testable and is more transparent in its underlying assumptions (Whitla et al., 2005; Zaheer et al., 2012). The 
article contributed to this debate in offering with new institutional economics a lens that is closely related to commonly applied frameworks in the field such as transaction costs economics and internalisation theory, both of which are related to new institutional economics. It embedded those in Yip's strategy framework because of its previous application to the international hotel strategy literature and the resulting familiarity of researchers with it.

This article also sheds further light on the recent discussion on the lack of benefits hotel chains received from 'plural-form' strategies i.e. a mix of equity and non-equity sites in host countries. Brokes and Roper (2012) identified as possible reasons the mind-set of the managers that play a decisive role in the exploitation of such a strategy. A common popular distinction in the literature based on equity and non-equity strategy might be only part of the story (Dunning \& McQueen, 1982; Alon et al., 2012). The present article provides a more structured avenue to investigate the phenomena based on more clearly defined theoretical propositions that might help to explain the lack of such exploitation by international hotels observed by the authors in the field.

Following Rugman et al. (2011) this article encourages to further explore the triangle between country, firm and subsidiary. Entry-modes have attracted the major share of research on international hotel strategy research (Dunning \& McQueen, 1982; Contractor \& Kundu, 1998) this might be because of the availability of Dunning's eclectic paradigm and the widely perceived suitability of it in order to explain that phenomena. Other topics, however; such as strategic development or streamlining of operations still stay in the background. Such topics should not be neglected, because the success or failure of such strategies might help shedding new light on older and often only in isolation studied phenomena in international hotel literature. The proposed lens might also open the door for further contributions of the field of international hotel strategy to the strategic management and wider international business literature as supported by Okumus (2002) for example. Given the progress made in the broader international business literature on institutional distance (e.g. Zaheer et al., 2012) it is seen as a valuable tool to investigate in more depth strategic issues in the international hospitality management literature and hence to contribute theoretically beyond the narrow field.

Furthermore, given the increasing attention given to multinational enterprises with their headquarters in developing countries (Gammeltoft, 2008; Peng et al., 2008), this article provides a framework which might help to understand their strategies.

For practitioners, this paper provides an analytical tool for managers striving to evaluate their international strategies. Given the availability of data sources such as the annual world economic forum survey (WEF) for formal institutions, as well as Hofstede's cultural dimensions (Hofstede, 1980) or Inglehard's world value survey (Inglehard et al., 2004) for informal institutions, this paper offers one way to apply such databases to inform strategic decision making at the headquarters. It also serves as a tool for subsidiary managers or contractors in remote host countries to understand headquarters decisions and to justify necessary requests to the headquarters for potential amendments to current strategic objectives.

Although the presented framework attempted to provide a clearer picture for the use of institutional distance on international hospitality management literature, it still suffers from some shortcomings. Most notably the recently emphasised importance of cities rather than regions or countries in international business (e.g. Johnson \& Vanetti, 2005; Beugelsdijk \& Mudambi, 2013, Dahms, 2015). From an empirical perspective, however; data collection on country level is already a daunting task for any international business researcher. Going below the country level and researching certain metropolitan areas is certainly a promising avenue for further research, but its practical obstacles concerning data availability, especially in emerging markets, might delay its application to the mainstream of international business research.

\section{Acknowledgements}

This paper benefitted from the comments received during the 'International College Interdisciplinary Seminar' (ICIS) series 2014/2015 at I-Shou University, Kaohsiung, Taiwan.

\section{References}

Alon, I., Ni, L., \& Wang, Y. (2012). Examining the determinants of hotel chain expansion through international franchising. International Journal of Hospitality Management, 31(2), 379-386. http://dx.doi.org/10.1016/j.ijhm.2011.06.009

Aramberri, J. (2009). The future of tourism and globalization: Some critical remarks. Futures, 41(6), 367-376. http://dx.doi.org/10.1016/j.futures.2008.11.015

Ayoun, B., \& Moreo, P. J. (2008). The influence of the cultural dimension of uncertainty avoidance on business strategy development: A cross-national study of hotel managers. International Journal of Hospitality 
Management, 27(1), 65-75. http://dx.doi.org/10.1016/j.ijhm.2007.07.008

Baum, T. (2006). Reflections on the nature of skills in the experience economy: Challenging traditional skills models in hospitality. Journal of Hospitality and Tourism Management, 13(2), 124-135. http://dx.doi.org/10.1375/jhtm.13.2.124

Beugelsdijk, S., \& Mudambi, R. (2013). MNEs as border-crossing multi-location enterprises: The role of discontinuities in geographic space. Journal of International Business Studies, 44(5), 413-426. http://dx.doi.org/10.1057/jibs.2013.23

Bouncken, R. (2002). Knowledge management for quality improvements in hotels. Journal of Quality Assurance in Hospitality \& Tourism, 3(3/4), 25-59. http://dx.doi.org/10.1300/J162v03n03_03

Brookes, M., \& Roper, A. (2012). Realising plural-form benefits in international hotel chains. Tourism Management, 33(3), 580-591. http://dx.doi.org/10.1016/j.tourman.2011.06.013

Brotherton, B. (1999). Towards a definitive view of the nature of hospitality and hospitality management. International Journal of Contemporary Hospitality Management, 11(4), 165-173. http://dx.doi.org/10.1108/09596119910263568

Buckley, P. J., \& Casson, M. (1976). The future of the multinational enterprise. London: Macmillan.

Chen, J. J., \& Dimou, I. (2005). Expansion strategy of international hotel firms. Journal of Business Research, 58(12), 1730-1740. http://dx.doi.org/10.1016/j.jbusres.2004.11.001

Contractor, F. J., Kundu, S. K., \& Hsu, C. C. (2003). A three-stage theory of international expansion: The link between multinationality and performance in the service sector. Journal of International Business Studies, 34(1), 5-18. http://dx.doi.org/10.1057/palgrave.jibs.8400003

Contractor, F. J., \& Kundu, S. K. (1998). Modal choice in a world of alliances: Analyzing organizational forms in the international hotel sector. Journal of International Business Studies, 29(2), 325-357. http://dx.doi.org/10.1057/palgrave.jibs.8490039

Crawford-Welch, S. (1991). International marketing in the hospitality industry. In R., Teare, \& A. Boer, (Eds.) Strategic Hospitality Management (pp. 166-193). London: Cassell.

Dahms, S. (2015). The effects of institutions and subsidiary competence on the international market orientation in foreign-owned subsidiaries. Management Research Review, 38(12). http://dx.doi.org/10.5539/ijbm.v9n3p27

Dahms, S. (2014). The Effects of Institutional Distance on Foreign-Owned Subsidiary Development: The Case of the Northwest of England. International Journal of Business and Management, 9(3), 27-42.

Davies, B. (1999). Industrial organization the UK hotel sector. Annals of Tourism Research, 26(2), 294-311. http://dx.doi.org/10.1016/S0160-7383(98)00096-6

De Jong, G., \& Van Vo, D. (2010). The impact of the institutional environment on the autonomy of MNCs' subsidiaries. Problems and Perspectives in Management, 8(2), 53-63.

DiMaggio, P., \& Powell, W. (1983). The iron cage revisited: Institutional isomorphism and collective rationality in organizational fields. American Sociological Review, 48(2), 147-160. http://dx.doi.org/10.2307/2095101

Dunning, J. H., Pak, Y. S., \& Beldona, S. (2007). Foreign ownership strategies of UK and US international franchisors: An exploratory application of Dunning's envelope paradigm. International Business Review, 16(5), 531-548. http://dx.doi.org/10.1016/j.ibusrev.2007.01.005

Dunning, J. H., \& McQueen, M. (1982). Multinational corporations in the international hotel industry. Annals of Tourism Research, 9(1), 69-90. http://dx.doi.org/10.1016/0160-7383(82)90035-4

Espino-Rodríguez, T. F., \& Padrón-Robaina, V. (2005). A resource-based view of outsourcing and its implications for organizational performance in the hotel sector. Tourism Management, 26(5), 707-721. http://dx.doi.org/10.1016/j.tourman.2004.03.013

Gammeltoft, P. (2008). Emerging multinationals: Outward FDI from the BRICS countries. International Journal of Technology and Globalisation, 4(1), 5-22. http://dx.doi.org/10.1504/IJTG.2008.016184

Gannon, J. M., Doherty, L., \& Roper, A. (2012). The role of strategic groups in understanding strategic human resource management. Personnel Review, 41(4), 513-546. http://dx.doi.org/10.1108/00483481211229401

Groschl, S., \& Doherty, L. (2006). The complexity of culture: Using the appraisal process to compare French and 
British managers in a UK-based international hotel organization. Hospitality Management, 25(2), 313-334. http://dx.doi.org/10.1016/j.ijhm.2005.04.002

Hallin, C. A., \& Marnburg, E. (2008). Knowledge management in the hospitality industry: A review of empirical research. Tourism Management, 29(2), 366-381. http://dx.doi.org/10.1016/j.tourman.2007.02.019

Harrington, R. J., \& Ottenbacher, M. C. (2011). Strategic management: An analysis of its representation and focus in recent hospitality research. International Journal of Contemporary Hospitality Management, 23(4), 439-462. http://dx.doi.org/10.1108/09596111111129977

Henisz, W., \& Williamson, O. E. (1999). Comparative economic organization-Within and between countries. Business and Politics, 1(3), 261-277. http://dx.doi.org/10.1515/bap.1999.1.3.261

Hofstede, G. (1980). Culture's consequences: international differences in work-related values. Sage: London.

Hsieh, A. T., \& Tsai, C. W. (2009). Does national culture really matter? Hotel service perceptions by Taiwan and American tourists. International Journal of Culture, Tourism and Hospitality Research, 3(1), 54-69.

Inglehart, R., Basanez, M., Diez-Medrano, J., Halman, L., \& Luijkx, R. (2004). Human Beliefs and Values: A Cross-cultural Sourcebook based on the 1999-2002. Values Surveys. Mexico City: Siglo Veintiuno Editores, S.A. de C.V.

Johnson, C., \& Vanetti, M. (2005). Locational strategies of international hotel chains. Annals of Tourism Research, 32(4), 1077-1099. http://dx.doi.org/10.1016/j.annals.2005.03.003

Knutsen, S. (2004). Financial systems and economic growth - A critical view on the 'business systems' literature. Paper presented to the DaNeNo workshop, Utrecht 4-5 June 2004. Retrieved from http://www.bintproject.nl/textfiles/2004_knutsen.pdf

Kogut, B., \& Singh, H. (1988). The effect of national culture on the choice of entry mode. Journal of International Business Studies, 19(3), 411-432. http://dx.doi.org/10.1057/palgrave.jibs.8490394

Kundu, S. K., Kumar, V., \& Peters, S. D. (2008). Impact of ownership and location factors on service multinationals' internalization. The Service Industries Journal, 28(5), 567-580. http://dx.doi.org/10.1080/02642060801988068

Langlois, R. (2006). The secret live of mundane transaction costs. Organisation Studies, 27, 1389-1414. http://dx.doi.org/10.1177/0170840606067769

León-Darder, F., Villar-García, C., \& Pla-Barber, J. (2011). Entry mode choice in the internationalisation of the hotel industry: A holistic approach. The Service Industries Journal, 31(1), 107-122. http://dx.doi.org/10.1080/02642069.2010.485198

Leung, K., Bhagat, R. S., Buchan, N. R., Erez, M., \& Gibson, C. B. (2005). Culture and international business: Recent advances and their implications for future research. Journal of International Business Studies, 36, 357-378. http://dx.doi.org/10.1057/palgrave.jibs. 8400150

Litteljohn, D., Roper, A., \& Altinay, L. (2007). Territories still to find-the business of hotel internationalization. International Journal of Service Industry Management, 18(2), 167-183. http://dx.doi.org/10.1108/09564230710737817

Lovelock, C. H., \& Yip, G. S. (1996). Developing Global Strategies for Service Businesses. California Management Review, 38(2), 64-86. http://dx.doi.org/10.2307/41165833

Martin, X. (2014). Institutional Advantage. Global Strategy Journal, 4(1), 55-69. http://dx.doi.org/10.1111/j.2042-5805.2013.01072.x

Martorell, O., Mulet, C., \& Otero, L. (2012). Choice of market entry mode by Balearic hotel chains in the Caribbean and Gulf of Mexico. International Journal of Hospitality Management, 32, 217-227. http://dx.doi.org/10.1016/j.ijhm.2012.06.001

North, D. C. (1990). Institutions, institutional change and economic performance. Cambridge university press: Cambridge. http://dx.doi.org/10.1017/CBO9780511808678

Oukumus, F. (2002). Can hospitality researchers contribute to the strategic management literature. Hospitality Management, 21, 105-110. http://dx.doi.org/10.1016/S0278-4319(01)00033-0

Olsen, M. D., Tse, E., \& West, J. J. (2008). Strategic management in the hospitality industry (3rd ed.). New York: Prentice Hall. 
Pine, R., \& Qi, P. (2004). Barriers to hotel chain development in China. International Journal of Contemporary Hospitality Management, 16(1), 37-44. http://dx.doi.org/10.1108/09596110410516543

Peng, M. W., Wang, D. Y., \& Jiang, Y. (2008). An institution-based view of international business strategy: A focus on emerging economies. Journal of International Business Studies, 39(5), 920-936. http://dx.doi.org/10.1057/palgrave.jibs. 8400377

Redding, G. (2005). The thick description and comparison of societal systems of capitalism. Journal of International Business Studies, 36, 123-155. http://dx.doi.org/10.1057/palgrave.jibs.8400129

Rugman, A. (2005). The Regional Multinationals: MNEs and "Global" Strategic Management. Cambridge: Cambridge University Press. http://dx.doi.org/10.1017/CBO9780511614071

Rugman, A., Verbeke, A., \& Nguyen, Q. T. K. (2011). Fifty years of international business theory and beyond. Management International Review, 51(6), 755-786. http://dx.doi.org/10.1007/s11575-011-0102-3

Rugman, A. M., \& Verbeke, A. (2008). A new perspective on the regional and global strategies of multinational

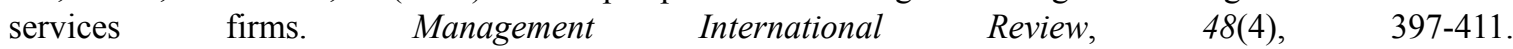
http://dx.doi.org/10.1007/s11575-008-0023-y

Rugman, A. M., \& Verbeke, A. (2001). Subsidiary-specific advantages in multinational enterprises. Strategic Management Journal, 22(3), 237-250. http://dx.doi.org/10.1002/smj.153

Shenkar, O. (2001). Cultural distance revisited: Towards a more rigorous conceptualization and measurement of cultural differences. Journal of International Business Studies, 32(3), 519-535. http://dx.doi.org/10.1057/palgrave.jibs.8490982

Thomas, D. C., Cuervo-Cazurra, A., \& Brannen, M. Y. (2011). From the editors: Explaining theoretical relationships in international business research: Focusing on the arrows, NOT the boxes. Journal of International Business Studies, 42(9), 1073-1078.

Verbeke, A., \& Greidanus, N. S. (2009). The end of the opportunism vs. trust debate: Bounded reliability as a new envelope concept in research on MNE governance. Journal of International Business Studies, 40(9), 1471-1495. http://dx.doi.org/10.1057/jibs.2009.44

Verbeke, A., \& Campbell, A. (2001). The Multinational Management of Multiple External Networks. In D. Van den Bulcke \& A. Verbeke (Eds.), Globalisation and the Small Open Economy. Cheltenham: Elgar. Ch. 10.

Villar, C., Pla-Barber, J., \& León-Darder, F. (2012). Service characteristics as moderators of the entry mode choice: Empirical evidence in the hotel industry. The Service Industries Journal, 32(7), 1137-1148. http://dx.doi.org/10.1080/02642069.2012.662497

Westney, D. E. (2005). Institutional theory and the multinational corporation. In S. Ghoshal, \& D. E. Westney, (Eds.), Organization theory and the multinational corporation. Palgrave Macmillan: Hampshire.

Whitla, P., Walters, P., \& Davies, H. (2007). Global strategies in the international hotel industry. International Journal of Hospitality Management, 26(4), 777-792. http://dx.doi.org/10.1016/j.ijhm.2006.08.001

Whitla, P., Walters, P., \& Davies, H. (2005). A critique of Yip's framework of global strategy. Paper Presented at the Asian Regional Academy of International Business Annual Conference, Manila, 23-25.

Williamson, O. E. (2000). The new institutional economics: Taking stock, looking ahead. Journal of Economic Literature, 38(3), 595-613. http://dx.doi.org/10.1257/jel.38.3.595

WEF. (2010). World Economic Forum. Global Competitiveness Report. Geneva: Author

Xu, D., \& Shenkar, O. (2002). Institutional distance and the multinational enterprise. Academy of Management Review, 27(4), 608-618.

Yang, J. T., \& Wan, C. S. (2004). Advancing organizational effectiveness and knowledge management implementation. Tourism Management, 25(5), 593-601. http://dx.doi.org/10.1016/j.tourman.2003.08.002

Yip, G. S. (1992). Total Global Strategy: Managing for Worldwide Competitive Advantage. Prentice-Hall: Englewood Cliffs.

Zaheer, S., Schomaker, M., \& Nachum, L. (2012). Distance without direction: Restoring credibility to a much-loved construct. Journal of International Business Studies, 43(1), 18-27. http://dx.doi.org/10.1057/jibs.2011.43

Zhang, H. Q., Guillet, B. D., \& Gao, W. (2012). What determines multinational hotel groups' locational 
investment choice in China? International Journal of Hospitality Management, 31(2), $350-359$. http://dx.doi.org/10.1016/j.ijhm.2011.05.008

Zhao, J. L., \& Olsen, M. D. (1997). The antecedent factors influencing entry mode choices of multinational lodging firms. International Journal of Hospitality Management, 16(1), $79-98$. http://dx.doi.org/10.1016/S0278-4319(96)00048-5

\section{Copyrights}

Copyright for this article is retained by the author(s), with first publication rights granted to the journal.

This is an open-access article distributed under the terms and conditions of the Creative Commons Attribution license (http://creativecommons.org/licenses/by/3.0/). 